\title{
Assessment of the importance of dissimilatory nitrate reduction to ammonium for the terrestrial nitrogen cycle
}

\author{
T. Rütting ${ }^{1}$, P. Boeckx ${ }^{2}$, C. Müller ${ }^{3,4}$, and L. Klemedtsson ${ }^{1}$ \\ ${ }^{1}$ Department of Plant and Environmental Sciences, University of Gothenburg, Box 461, 40530 Gothenburg, Sweden \\ ${ }^{2}$ Laboratory of Applied Physical Chemistry - ISOFYS, Ghent University, Coupure 653, 9000 Gent, Belgium \\ ${ }^{3}$ Department of Plant Ecology, Justus-Liebig University Giessen, Heinrich-Buff-Ring 26, 35392 Giessen, Germany \\ ${ }^{4}$ School of Biology and Environmental Sciences, University College Dublin, Belfield, Dublin 4, Ireland
}

Received: 7 January 2011 - Published in Biogeosciences Discuss.: 9 February 2011

Revised: 22 June 2011 - Accepted: 4 July 2011 - Published: 8 July 2011

\begin{abstract}
The nitrogen $(\mathrm{N})$ cycle contains two different processes of dissimilatory nitrate $\left(\mathrm{NO}_{3}^{-}\right)$reduction, denitrification and dissimilatory $\mathrm{NO}_{3}^{-}$reduction to ammonium (DNRA). While there is general agreement that the denitrification process takes place in many soils, the occurrence and importance of DNRA is generally not considered. Two approaches have been used to investigate DNRA in soil, (1) microbiological techniques to identify soil microorganisms capable of DNRA and (2) ${ }^{15} \mathrm{~N}$ tracing to elucidate the occurrence of DNRA and to quantify gross DNRA rates. There is evidence that many soil bacteria and fungi have the ability to perform DNRA. Redox status and $\mathrm{C} / \mathrm{NO}_{3}^{-}$ratio have been identified as the most important factors regulating DNRA in soil. ${ }^{15} \mathrm{~N}$ tracing studies have shown that gross DNRA rates can be a significant or even a dominant $\mathrm{NO}_{3}^{-}$consumption process in some ecosystems. Moreover, a link between heterotrophic nitrification and DNRA provides an alternative pathway of ammonium $\left(\mathrm{NH}_{4}^{+}\right)$production to mineralisation. Numerical ${ }^{15} \mathrm{~N}$ tracing models are particularly useful when investigating DNRA in the context of other $\mathrm{N}$ cycling processes. The results of correlation and regression analyses show that highest gross DNRA rates can be expected in soils with high organic matter content in humid regions, while its relative importance is higher in temperate climates. With this review we summarise the importance and current knowledge of this often overlooked $\mathrm{NO}_{3}^{-}$consumption process within the terrestrial $\mathrm{N}$ cycle. We strongly encourage considering DNRA as a relevant process in future soil $\mathrm{N}$ cycling investigations.
\end{abstract}

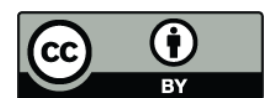

Correspondence to: T. Rütting (tobias.rutting@dpes.gu.se)

\section{Introduction}

Our understanding of the nitrogen $(\mathrm{N})$ cycle has increased in recent years due to newly discovered processes and the finding that various groups of microorganisms are involved in $\mathrm{N}$ transformations, e.g. archaeal ammonia $\left(\mathrm{NH}_{3}\right)$ oxidation and codenitrification (Hayatsu et al., 2008; Francis et al., 2007). Among the many processes that constitute the $\mathrm{N}$ cycle are two processes of dissimilatory nitrate $\left(\mathrm{NO}_{3}^{-}\right)$reduction that occur under similar conditions of low oxygen concentrations (Tiedje et al., 1982): denitrification, which is the reduction of $\mathrm{NO}_{3}^{-}$to gaseous $\mathrm{N}$ compounds $\left(\mathrm{NO}, \mathrm{N}_{2} \mathrm{O}\right.$ and $\mathrm{N}_{2}$ ), and dissimilatory $\mathrm{NO}_{3}^{-}$reduction to ammonium $\left(\mathrm{NH}_{4}^{+}\right)$(DNRA), which is also termed fermentative $\mathrm{NO}_{3}^{-}$reduction, $\mathrm{NO}_{3}^{-}$ammonification or fermentative ammonification. In both processes nitrite $\left(\mathrm{NO}_{2}^{-}\right)$is an intermediate product (Philippot and Højberg, 1999). Hence, our discussion on DNRA is in most points equally valid for dissimilatory $\mathrm{NO}_{3}^{-}$and $\mathrm{NO}_{2}^{-}$ reduction.

As early as 1938, Woods showed that DNRA occurs in common soil bacteria like Clostridium welchii. Furthermore, he pointed out the need to simultaneously investigate various $\mathrm{N}$ cycle processes by concluding that DNRA "must be seriously considered in assessing the importance of the oxidation of $\mathrm{NH}_{3}$ to $\mathrm{NO}_{3}$ by other micro-organisms in the general circulation of $\mathrm{N}$ in nature" (Woods, 1938). This view was supported later by Stanford et al. (1975) who used ${ }^{15} \mathrm{~N}$ tracing techniques. They stated that "results seriously challenge the prevalent view that denitrification accounts for essentially all $\mathrm{NO}_{3}^{-}$dissimilation in anaerobic soils". However, most investigations still consider denitrification as the only dissimilatory $\mathrm{NO}_{3}^{-}$reduction process in soil (Cole, 1990). The principal importance of DNRA is that $\mathrm{NO}_{3}^{-}$is transferred into

Published by Copernicus Publications on behalf of the European Geosciences Union. 
another mineral $\mathrm{N}$ form which is less mobile and thus, in contrast to denitrification, may conserve $\mathrm{N}$ in the ecosystem (Buresh and Patrick, 1978; Tiedje, 1988). Therefore, DNRA has been called a "short circuit in the biological $\mathrm{N}^{-}$cycle" (Cole and Brown, 1980), as the direct transfer of $\mathrm{NO}_{3}^{-}$and $\mathrm{NO}_{2}^{-}$to $\mathrm{NH}_{4}^{+}$bypasses denitrification and $\mathrm{N}_{2}$ fixation.

Nitrate and $\mathrm{NO}_{2}^{-}$reduction during DNRA are catalysed by two different sets of enzymes of which the first is respiratory while the second is fermentative (Moreno-Vivián and Ferguson, 1998; Simon, 2002; Mohan et al., 2004). Since both mechanisms are dissimilatory (Moreno-Vivián and Ferguson, 1998) and can be expected to have similar ecological relevance for $\mathrm{N}$ retention, they will be considered together in this review.

Based on a comparison of the potential free energy of total denitrification $\left(\mathrm{NO}_{3}^{-} \rightarrow \mathrm{N}_{2},-2669 \mathrm{~kJ} \mathrm{~mol}^{-1}\right.$ glucose $)$ and DNRA (-1796 kJ mol ${ }^{-1}$ glucose; Gottschalk, 1986), denitrification should be favoured over DNRA. However, under $\mathrm{NO}_{3}^{-}$limiting and strongly reducing conditions, a shortage of electron acceptors is most likely limiting microbial growth. Under these conditions DNRA has the advantage over denitrification since more electrons can be transferred per mole $\mathrm{NO}_{3}^{-}$(Tiedje et al., 1982). Additionally the potential free energy calculated per mole $\mathrm{NO}_{3}^{-}$is higher for DNRA than denitrification (Tiedje et al., 1982; Strohm et al., 2007). By comparing the growth yield of denitrifiers and DNRA bacteria in pure culture, Strohm et al. (2007) showed that the actual energy yield of denitrification was much lower than what was expected from the free energy and even lower than the actual energy yield of DNRA, which was discussed as a consequence of inefficient energy conservation by denitrifiers. Consequently, during DNRA twice as much cell mass was synthesised per mole of $\mathrm{NO}_{3}^{-}$compared to denitrification (Strohm et al., 2007). These findings support the hypothesis that the ratio of electron donor to acceptor (i.e. available $\mathrm{C}$ to $\mathrm{NO}_{3}^{-}$) is an important factor in the partitioning of $\mathrm{NO}_{3}^{-}$ reduction between denitrification and DNRA (Tiedje et al., 1982). DNRA is favoured under higher $\mathrm{C} / \mathrm{NO}_{3}^{-}$ratios when the electron acceptor $\left(\mathrm{NO}_{3}^{-}\right)$becomes limiting (Tiedje et al., 1982).

While the importance of DNRA in marine ecosystems (Burgin and Hamilton, 2007), the responsible enzymes and bioenergetics (Philippot and Højberg, 1999; Simon, 2002; Takaya, 2002; Kraft et al., 2011) as well as molecular techniques to track DNRA microorganisms (Philippot, 2005) were recently reviewed no such current review is available for DNRA in soils. In recent years $\mathrm{N}$ cycling studies have increasingly investigated DNRA in various ecosystems. Thus we think it is timely to revisit this often forgotten process, summarise the current knowledge of DNRA in terrestrial ecosystems and to explore its importance for soil $\mathrm{N}$ cycling. We will discuss how various environmental factors influence DNRA in soil and approaches to investigate the importance of DNRA in soil. Two approaches have been used: first, mi- crobiological techniques have been applied to identify soil microorganisms capable of performing DNRA and to assess their abundance, in particular in comparison with denitrifying microbes; second, ${ }^{15} \mathrm{~N}$ has been used as a tracer to qualitatively investigate $\mathrm{NH}_{4}^{+}$production from added ${ }^{15} \mathrm{NO}_{3}^{-}$in order to elucidate if DNRA occurs in soil. Moreover, ${ }^{15} \mathrm{~N}$ tracing techniques also allow the quantification of gross rates for DNRA, which will be highlighted in this review.

\section{Environmental conditions for DNRA}

The soil oxidation state is a principal factor that influences the importance of DNRA compared to denitrification (Matheson et al., 2002; Brunel et al., 1992) with DNRA by bacteria and fungi occurring under more reducing (anoxic) conditions (Takaya, 2002; Yin et al., 2002; Page et al., 2003). On the other hand, other studies showed that DNRA is less sensitive to variable redox conditions (Pett-Ridge et al., 2006) and less sensitive to $\mathrm{O}_{2}$ than denitrification (Fazzolari et al., 1998). In the later study soil aggregates were incubated under various $\mathrm{O}_{2}$ levels with the same $\mathrm{NO}_{3}^{-}$concentrations combined with different levels of glucose $\mathrm{C}$ additions. The authors showed that the effect of variable $\mathrm{O}_{2}$ on DNRA was dependent on the $\mathrm{C} / \mathrm{NO}_{3}^{-}$ratio and concluded that $\mathrm{C}$ rather than $\mathrm{O}_{2}$ was the key factor regulating $\mathrm{NO}_{3}^{-}$partitioning between denitrification and DNRA (Fazzolari et al., 1998). This study as well as the one by Smith (1982) confirmed the importance of the $\mathrm{C} / \mathrm{NO}_{3}^{-}$ratio on partitioning $\mathrm{NO}_{3}^{-}$reduction between DNRA and denitrification as hypothesised by Tiedje et al. (1982). Yin et al. (1998) showed that significant DNRA occurred only at a $\mathrm{C} / \mathrm{NO}_{3}^{-}$ratio above 12 . However, Matheson et al. (2002) argued that the effect of $\mathrm{C} / \mathrm{NO}_{3}^{-}$ratio on DNRA may be an artefact of experimental approaches. Experiments investigating DNRA under different $\mathrm{C} / \mathrm{NO}_{3}^{-}$ratios usually artificially alter either the organic $\mathrm{C}$ or $\mathrm{NO}_{3}^{-}$content that can result in enhanced $\mathrm{O}_{2}$ consumption due to stimulation of microbial activity or in altered soil redox potential due to that $\mathrm{NO}_{3}^{-}$is an oxidising agent itself (Matheson et al., 2002). Therefore, Matheson et al. (2002) concluded that experimental evidence of the effect of $\mathrm{C} / \mathrm{NO}_{3}^{-}$ratio are most likely due to altered soil oxidation state, which is hence the key partitioning factor. However, in a tropical forest the natural difference in the $\mathrm{C} / \mathrm{NO}_{3}^{-}$ratio explained $44 \%$ of the variability of gross DNRA rates determined by an in-situ ${ }^{15} \mathrm{~N}$ tracing experiment (Silver et al., 2005). In contrast, in a laboratory incubation with intact soil cores from another tropical forest no correlation between DNRA and $\mathrm{C} / \mathrm{NO}_{3}^{-}$was detected (Sotta et al., 2008). These contrasting results could be due to the occurrence of DNRA in anaerobic micro-sites and that the bulk soil $\mathrm{C} / \mathrm{NO}_{3}^{-}$ratio may not be a representative indicator for the ratio at the site of activity.

Tiedje et al. (1988) pointed out that it is the availability of a suitable organic $\mathrm{C}$ source, supporting respiration or fermentation, that regulates the population of DNRA 
bacteria. Several studies showed that the addition of glucose, a carbohydrate that supports respiration as well as fermentation, stimulated DNRA (Buresh and Patrick, 1978; Smith and Zimmerman, 1981; Yin et al., 2002; Caskey and Tiedje, 1979; Fazzolari Correa and Germon, 1991; Yin et al., 1998). In a ${ }^{15} \mathrm{~N}$ labelling study with soil slurries Morley and Baggs (2010) reported that DNRA appeared to be stimulated more by carbohydrates (glucose and mannitol) than amino acids and butyrate, but Yin et al. (1998) reported that the carbohydrates glycerol and succinate do not support DNRA. Moreover, in two anaerobic soils, addition of glucose did not influence DNRA (Chen et al., 1995). Chen et al. (1995) identified several possible explanations, including the high native soil $\mathrm{C}$ content compared to the amount of added glucose, unfavourable redox conditions for DNRA or effects of soil rewetting. DeCatanzaro et al. (1987) also did not find an effect of glucose addition on DNRA, but revealed that DNRA was stimulated by alfalfa addition. This was apparently an effect of sulphur in alfalfa, which was released as -SH group during sulphur mineralisation of organic matter and served as reducing agent. Under anaerobic conditions, sulphide stimulates DNRA, by serving as an electron donor, and depresses denitrification, by repressing $\mathrm{NO}$ and $\mathrm{N}_{2} \mathrm{O}$ reductase (Myers, 1972; Brunet and Garcia-Gill, 1996). In this line DeCatanzaro et al. (1987) found in the above mentioned study a stimulation of DNRA when simultaneously adding glucose and sulphide, which contrasted the finding from only glucose addition.

Other C sources, like straw, glycerol, methanol and succinate did not promote DNRA (Buresh and Patrick, 1978; deCatanzaro et al., 1987; Yin et al., 1998). The reasons for this are not fully understood and deserve further investigations. Buresh and Patrick (1978) as well as Yin et al. (1998) attributed this finding to the fact that the mentioned $\mathrm{C}$ sources are poor substrates for fermentation. As DNRA was thought to be a solely fermentative process (Cole and Brown, 1980) these substrates hence also did not promote DNRA. However, as two distinct pathways of DNRA exist, one fermentative and one respiratory (Moreno-Vivián and Ferguson, 1998; Simon, 2002; Mohan et al., 2004), this can not be the sole explanation. For the respiratory DNRA Simon (2002) listed formate, $\mathrm{H}_{2}$ and sulphide as substrates. Possibly the above mentioned $\mathrm{C}$ sources do neither favour the fermentative nor the respiratory DNRA pathway. This may also explain why in some cases addition of glucose does not support DNRA and some of the above mentioned contradictions in the response to $\mathrm{C} / \mathrm{NO}_{3}^{-}$, as this may depend on whether respiratory or fermentative DNRA bacteria are present. This is supported by DeCatanzaro et al. (1987) in respect to sulphide.

Several studies investigated the effect of $\mathrm{pH}$ on DNRA, though findings were partly contradictory. Higher DNRA was associated with alkaline conditions (Nõmmik, 1956; Stevens et al., 1998; Fazzolari Correa and Germon, 1991; Gamble et al., 1977) and Woods (1938) reported a pH optimum of 6.5 for $\mathrm{NO}_{2}^{-}$reduction and of 7.5 for $\mathrm{NO}_{3}^{-}$re- duction. In contrast other studies found a negative relationship between DNRA and soil pH (Davidson and Ståhl, 2000; Waring and Gilliam, 1983). For denitrification many studies found an effect of $\mathrm{pH}$, however it appeared that this effect may be indirect due to changes in the availability of organic C (Šimek and Cooper, 2002). Under acidic conditions the slow breakdown of organic matter decreases the availability of organic $\mathrm{C}$ for microorganisms and, hence, denitrification. It is unknown if this is also the case for DNRA, but Waring and Gilliam (1983) reported that DNRA increased at lower $\mathrm{pH}(<4)$ in poorly drained soils, which was linked to the soluble $\mathrm{C}$ content. Therefore, contrasting findings of the $\mathrm{pH}$ effect on DNRA may partly be related to soil $\mathrm{C}$ availability and, hence, be of indirect nature.

Taken together, the oxidation status and the $\mathrm{C} / \mathrm{NO}_{3}^{-}$ratio appear to be the most important factors regulating the importance of DNRA in soil, while the effect of $\mathrm{pH}$ was not consistent. Other investigations found a correlation between DNRA and SOM, moisture or soil N (Gamble et al., 1977; Davidson and Ståhl, 2000). However, there are not enough data available in the literature to make a comprehensive analysis on the importance of the various factors. Hence, studies are needed to systematically investigate the main controlling factors of DNRA in soil.

\section{Effects of plants on DNRA in soils}

The presence of roots alters the activity and abundance of dissimilatory $\mathrm{NO}_{3}^{-}$reducers in soils, as a consequence of altered substrate and oxygen availability (Philippot et al., 2009). It is well established that denitrification is generally stimulated by the presence of roots, due to exudates and oxygen consumption (Klemedtsson et al., 1987; Woldendorp, 1963). However, no study has investigated the direct effect of plants on DNRA in upland soils, but some information is available for wetland/freshwater plants, though findings are not conclusive. In the presence of reed sweetgrass (Glyceria maxima) DNRA bacteria (53\%) dominated the $\mathrm{NO}_{3}^{-}$ reducer community in a pot experiment (Nijburg and Laanbroek, 1997a), while in unplanted soil denitrifiers dominated (71\%). In contrast, the presence of reed (Thypha angustifolia) had little effect on the functional groups of $\mathrm{NO}_{3}^{-}$reducers, with DNRA bacteria accounting for 12 and $19 \%$ in the bulk and rhizospheric sediment from a freshwater lake, respectively (Brunel et al., 1992). A higher contribution of DNRA to the recovery of added ${ }^{15} \mathrm{NO}_{3}^{-}$was found in soil cores containing reed roots compared to root free cores (Nijburg and Laanbroek, 1997b). In contrast a ${ }^{15} \mathrm{NO}_{3}^{-}$labelling microcosm study found that DNRA accounted for $49 \%$ of $\mathrm{NO}_{3}^{-}$consumption in unplanted soil, while in the presence of plants DNRA accounted for less than $1 \%$ (Matheson et al., 2002). At the same time denitrification was higher in the planted soil. A riparian zone study by Dhondt et al. (2003) also showed that during the growing season denitrification 
was dominant while DNRA predominated when plant activity was low.

Effective soil $\mathrm{N}$ retention is achieved by a tight coupling of DNRA with plant (and microbial) $\mathrm{NH}_{4}^{+}$uptake as was observed in tropical upland soils (Templer et al., 2008). This highlights the need to better understand plant interactions with DNRA and $\mathrm{N}$ retention in upland soils by conducting parallel studies with planted and unplanted soils. Apart from assimilation, $\mathrm{N}$ retention may also occur due to adsorption of $\mathrm{NH}_{4}^{+}$, produced via DNRA, on clay minerals or organic matter, and is governed by the cation exchange capacity.

\section{Production of $\mathrm{N}_{2} \mathrm{O}$ during DNRA}

DNRA is generally seen as a process that conserves $\mathrm{N}$ in the ecosystem. However, many microorganisms conducting DNRA also produce $\mathrm{N}_{2} \mathrm{O}$ (Cole, 1988). Kaspar (1982) suggested that $\mathrm{N}_{2} \mathrm{O}$ production by DNRA microorganisms is a detoxification mechanism, in order to avoid high concentrations of $\mathrm{NO}_{2}^{-}$. In a batch culture, a soil Citrobacter $s p$. produced $\mathrm{N}_{2} \mathrm{O}$ and $\mathrm{NH}_{4}^{+}$by enzymatically reducing $\mathrm{NO}_{2}^{-}$ (Smith, 1982). The use of ${ }^{13} \mathrm{NO}_{3}^{-}$labelling proved that several microorganisms were able to simultaneously produce $\mathrm{NH}_{4}^{+}$and $\mathrm{N}_{2} \mathrm{O}$ via dissimilatory pathways, whereby $\mathrm{NH}_{4}^{+}$ accounted typically for $>90 \%$ of the total product (Bleakley and Tiedje, 1982). This finding is in line with an anaerobic batch incubation study where all DNRA isolates from three different soils showed $\mathrm{N}_{2} \mathrm{O}$ production, which accounted for 5-10\% of added $\mathrm{NO}_{3}^{-}$(Smith and Zimmerman, 1981). However, as stated by Cole (1988), the $\mathrm{N}_{2} \mathrm{O}$ production rate by DNRA microorganisms is typically in the range of $1 \%$ of the $\mathrm{NO}_{2}^{-}$or $\mathrm{NO}_{3}^{-}$reduction. Based on a ${ }^{15} \mathrm{NO}_{3}^{-}$labelling study, Stevens et al. (1998) concluded that DNRA became a more important process for $\mathrm{N}_{2} \mathrm{O}$ production with increasing $\mathrm{pH}$, possibly as a mechanism to reduce harmful $\mathrm{NO}_{2}^{-}$ that tended to accumulate under high $\mathrm{pH}$. However, as both DNRA and denitrification use the same substrates $\left(\mathrm{NO}_{3}^{-}\right.$and $\mathrm{NO}_{2}^{-}$) the contribution of these two processes to total $\mathrm{N}_{2} \mathrm{O}$ production can not be investigated based on ${ }^{15} \mathrm{NO}_{3}^{-}$labelling alone. Thus the identification of the responsible microorganisms is required (Stevens et al., 1998). To achieve this, quantifying enzyme activity rather than investigating microbial species or functional genes is needed, as discussed for linking denitrifier density to functioning by Philippot and Hallin (2005).

\section{Soil microorganisms involved in DNRA}

The aim of this section is to summarise studies that compared the abundance of soil DNRA microorganisms to denitrifiers. The capability for $\mathrm{NO}_{3}^{-}$respiration and for DNRA is widely spread among bacteria (Philippot, 2005; Simon, 2002). Tiedje (1988) listed several genera of soil DNRA bac- teria, which are either obligate anaerobes (Clostridium), facultative anaerobes (Citrobacter, Enterobacter, Erwinia, Escherichia, Klebsiella) or aerobes (Bacillus, Pseudomonas), and recently DNRA been shown for several rhizobial species (Polcyn and Podeszwa, 2009). In addition a soil Arthrobacter strain, an abundant soil genus worldwide which is regarded as an obligate aerobe, showed DNRA when incubated anaerobically (Eschbach et al., 2003). This was also shown for eight Nitrobacter strains that were regarded as obligate aerobe $\mathrm{NO}_{2}^{-}$oxidiser (Freitag et al., 1987). Moreover, the capability for DNRA is widely distributed among common soil fungi, mostly belonging to the ascomycota (Zhou et al., 2002). Many bacteria capable of DNRA are found in the Enterobacteriacea, which is the only group of procaryotes with no known denitrifier (Zumft, 1997). Mohan and Cole (2007) pointed out that there is no known bacterium capable of both, denitrification and DNRA. Recently, however, Behrendt et al. (2010) provided evidence by growth tests that two newly described Paenibacillus species, including one fen soil isolate, showed a versatile metabolism and were capable of heterotrophic nitrification, DNRA and denitrification. Moreover, Zhou et al. (2002) showed that denitrification and DNRA are alternatively expressed in a common soil fungus (Fusarium oxysporum) depending on oxygen status and available $C$ source (Zhou et al., 2002). These authors classified the metabolism of this fungus depending on $\mathrm{O}_{2}$ status as: DNRA under anoxic conditions, denitrification when $\mathrm{O}_{2}$ supply was limited and aerobic respiration under sufficient $\mathrm{O}_{2}$ supply.

Microorganisms which reduce $\mathrm{NO}_{3}^{-}$via a dissimilatory pathway can be classified either as (a) denitrifiers, producing gaseous $\mathrm{N}$ compounds, (b) $\mathrm{NO}_{2}^{-}$accumulators which reduce $\mathrm{NO}_{3}^{-}$only to $\mathrm{NO}_{2}^{-}$, or (c) DNRA microorganisms that reduce $\mathrm{NO}_{3}^{-}$or $\mathrm{NO}_{2}^{-}$to $\mathrm{NH}_{4}^{+}$. Several authors compared the abundance of DNRA and denitrifying bacteria in soils, which, however, does not provide information on the activity of these bacterial groups in soil. This would require alternative approaches, e.g. ${ }^{15} \mathrm{~N}$ labelling as discussed below (Sect. 6). Evidence for a direct competition between DNRA bacteria and denitrifiers for $\mathrm{NO}_{3}^{-}$comes from a soil inoculation study using ${ }^{15} \mathrm{NO}_{3}^{-}$as a tracer (see Sect. 6) (Fazzolari et al., 1990). When a non-sterile soil was inoculated with the DNRA bacterium Enterobacter amnigenus, the production of ${ }^{15} \mathrm{NH}_{4}^{+}$ from ${ }^{15} \mathrm{NO}_{3}^{-}$increased compared to non-inoculated control soil while at the same time $\mathrm{N}_{2} \mathrm{O}$ production decreased. In contrast, inoculation with the denitrifier Agrobacterium radiobacter resulted in faster $\mathrm{N}_{2} \mathrm{O}$ production while no ${ }^{15} \mathrm{NH}_{4}^{+}$ was produced. Simultaneous inoculation with both bacteria resulted in intermediate results (Fazzolari et al., 1990).

Studies, investigating microorganisms with a dissimilatory $\mathrm{NO}_{3}^{-}$reduction pathway, often found that non-denitrifying $\mathrm{NO}_{3}^{-}$reducers were most abundant. In all 19 soils investigated by Gamble et al. (1977) the number of $\mathrm{NO}_{2}^{-}$accumulators outnumbered denitrifiers, with an average ratio of $4: 1$. 
This is consistent with the ratio of 4:1-3:1 for DNRA bacteria to denitrifiers in soil reported by Tiedje et al. (1982) and agrees with Bengtsson and Bergwall (2000) who reported a higher number of DNRA bacteria than denitrifiers for a spruce forest soil. Moreover, Smith and Zimmerman (1981) found that non-denitrifying bacteria dominated $\mathrm{NO}_{3}^{-}$reducers, but most were $\mathrm{NO}_{2}^{-}$accumulators. However, the majority of $\mathrm{NO}_{2}^{-}$accumulators were capable of DNRA when $\mathrm{NO}_{3}^{-}$was limited (Smith and Zimmerman, 1981), which was also found in a Klebsiella sp. (Dunn et al., 1979). In contrast, Brunel et al. (1992) found that, after addition of glycerol, only few strains of $\mathrm{NO}_{2}^{-}$accumulators were capable of DNRA but more were able to produce $\mathrm{N}_{2} \mathrm{O}$. In this context it is interesting to notice that the growth of the DNRA bacterium Enterobacter amnigenus was only related to $\mathrm{NO}_{3}^{-}$reduction to $\mathrm{NO}_{2}^{-}$but not to the reduction of $\mathrm{NO}_{2}^{-}$to $\mathrm{NH}_{4}^{+}$ (Fazzolari et al., 1990). These authors concluded that $\mathrm{NO}_{2}^{-}$ reduction may serve as an electron sink but not for energy generation. In three paddy soils, the number of DNRA bacteria was only $19-35 \%$ of the number of denitrifiers (Yin et al., 1998). However, in two other paddy soils Yin et al. (2002) found that the number of DNRA was higher than denitrifiers when the soil was pre-incubated or when $\mathrm{C}$ was added, which again points to the importance of $\mathrm{C}$ as discussed in Sect. 2 .

However, all discussed results are based on culturable microorganisms. Moreover, the activity of a DNRA bacterium differed between pure culture and soil inoculation (Fazzolari et al., 1990). Investigating the abundance of bacteria by functional genes, Kandeler et al. (2009) reported that denitrifiers accounted for less than half of the total $\mathrm{NO}_{3}^{-}$reducer community in a forest soil. Molecular approaches for studying the microbial community of $\mathrm{NO}_{3}^{-}$reducers in-situ were recently reviewed by Philippot (2005) and are therefore not repeated here. The review by Philippot (2005) highlighted the importance of functional genes, of culture independent approaches and of quantitative information when investigating denitrifier and $\mathrm{NO}_{3}^{-}$reducer communities. Moreover, to link microbial diversity with functional activity Philippot and Hallin (2005) pointed out the need for investigating enzyme activities rather than functional genes (DNA as well as mRNA). This could provide a strong tool for investigating and comparing the DNRA and denitrification activity in soil.

\section{Investigating DNRA by ${ }^{15} \mathrm{~N}$ tracing techniques}

${ }^{15} \mathrm{~N}$ tracing techniques are commonly used to investigate the fate of $\mathrm{N}$ in terrestrial ecosystems (Hart and Myrold, 1996). These techniques are also used to quantify gross transformation rates (see Sect. 6.2). To confirm the occurrence of DNRA in soil, various researchers applied ${ }^{15} \mathrm{NO}_{3}^{-}$and measured the ${ }^{15} \mathrm{~N}$ enrichment of $\mathrm{NH}_{4}^{+}$after incubation. Commonly, these studies applied also $\mathrm{NH}_{4}^{+}$to inhibit immobilisation of $\mathrm{NO}_{3}^{-}$due to high $\mathrm{NH}_{4}^{+}$concentrations. If $\mathrm{NO}_{3}^{-}$ immobilisation occurred at significant rates, ${ }^{15} \mathrm{~N}$ enrichment of $\mathrm{NH}_{4}^{+}$may also be the result of immobilisation (i.e. assimilatory $\mathrm{NO}_{3}^{-}$reduction) and subsequent remineralisation. However, there seems to be no study that has systematically investigated if the assumption of negligible $\mathrm{NO}_{3}^{-}$immobilisation holds true.

\section{1 $\quad{ }^{15} \mathrm{~N}$ labelling to confirm DNRA occurrence}

More than 50 years ago Nõmmik (1956) showed that a small amount of added ${ }^{15} \mathrm{NO}_{3}^{-}$was converted to $\mathrm{NH}_{4}^{+}$, but only under strictly anaerobic conditions. Therefore, it was concluded that DNRA is "extremely insignificant" under the prevailing conditions in arable soil (Nõmmik, 1956). This was also true for six tropical soils from the Philippines, where only a small fraction $(<2 \%)$ of added ${ }^{15} \mathrm{NO}_{3}^{-}$was recovered as $\mathrm{NH}_{4}^{+}$(MacRae et al., 1968). After incubating ten agricultural soils with varying texture and properties, Fazzolari Correa and Germon (1991) showed that $10-38 \%$ of added ${ }^{15} \mathrm{NO}_{3}^{-}$was reduced to $\mathrm{NH}_{4}^{+}$via DNRA when a labile $\mathrm{C}$ source was added. This is in the same range as found by Stanford et al. (1975) and Wan et al. (2009). In these studies only very small amounts of ${ }^{15} \mathrm{NO}_{3}^{-}$were recovered as ${ }^{15} \mathrm{NH}_{4}^{+}$without addition of labile C. However, Fazzolari Correa and Germon (1991) pointed out that all the conditions required for DNRA can be present in agricultural soils. Furthermore, several studies using anaerobic soil incubations attributed ${ }^{15} \mathrm{NO}_{3}^{-}$recovery as ${ }^{15} \mathrm{NH}_{4}^{+}$to DNRA (Buresh and Patrick, 1978; Ambus et al., 1992; Chen et al., 1995; Dhondt et al., 2003; Yin et al., 1998).

In soil cores from a riparian fen, DNRA was only detected below a depth of $5 \mathrm{~cm}$ (Ambus et al., 1992). However, when the same soil was incubated as slurry, DNRA did not differ between three soil layers $(0-5,5-10$ and $10-20 \mathrm{~cm})$, but the ratio of DNRA to total $\mathrm{NO}_{3}^{-}$reduction increased with depth (Ambus et al., 1992). This finding points to the effect that experimental conditions (e.g. soil slurry vs. core incubation) can have on experimental results, which impedes the comparison of results from different studies. Another riparian buffer zone study using slurry incubations showed that DNRA was only significant during the dormant season. This was attributed to low redox potentials and high inputs of labile $\mathrm{C}$ during that time (Dhondt et al., 2003). The studies by Ambus et al. (1992) and Dhondt et al. (2003) both point to the occurrence of DNRA under more reduced conditions compared to denitrification. However, some studies indicated that DNRA and denitrification can occur simultaneously in soil (Paul and Beauchamp, 1989; Stevens and Laughlin, 1998; Morley and Baggs, 2010), possibly in different micro-sites that differ in redox state. Furthermore, in contrast to Ambus et al. (1992), slurry incubations with soil from a riparian zone by Davis et al. (2008) resulted in higher DNRA rates in the surface soil $(0-15 \mathrm{~cm})$ compared to sub-soil $(130-155 \mathrm{~cm})$. A similar result was observed in an adjacent cropping system. The different results between the two studies may be related to 
different soil depths investigated, due to changing substrate availability and redox conditions with depth.

\subsection{Gross DNRA transformation rates}

Higher numbers of DNRA microorganisms compared to denitrifiers may not necessarily reflect a higher DNRA activity in soil. Thus, investigations of gross transformation rates are needed to evaluate the importance of DNRA. This can be achieved by ${ }^{15} \mathrm{~N}$ labelling techniques in conjunction with data analysis via analytical or numerical models. Most ${ }^{15} \mathrm{~N}$ labelling studies to date did not consider DNRA, because it was assumed to be a negligible process. Here, we will summarise gross DNRA rates reported from soils and explore if DNRA is indeed negligible or must be considered as an important $\mathrm{N}$ pathway in soil.

The first reported gross DNRA rate measurement in soils was presented by Ambus et al. (1992) for a riparian fen. Unfortunately, no equation for the calculation of the gross rates was provided. An analytical solution to calculate gross rates for DNRA, based on the increase of the ${ }^{15} \mathrm{~N}$ enrichment of the $\mathrm{NH}_{4}^{+}$pool after addition of ${ }^{15} \mathrm{NO}_{3}^{-}$as a tracer, was developed by Silver et al. (2001) (the actual equations are presented in: Huygens et al., 2008). The derived analytical equations were applied to investigate DNRA in various ecosystems, mostly tropical forest soils (Table 1). Several studies showed that DNRA was a significant and sometimes dominant fate of $\mathrm{NO}_{3}^{-}$in terrestrial ecosystems (Table 1). Some studies compared DNRA and denitrification rates. In a tropical forest soil DNRA was threefold higher than denitrification (Silver et al., 2001) and in a spruce forest the gross rate of DNRA was three orders of magnitude higher than gross denitrification (Bengtsson and Bergwall, 2000). This was also found for freshly sampled soil from another tropical forest (Pett-Ridge et al., 2006). However, when this soil was pre-incubated for 3-6 weeks under different redox regimes denitrification exceeded DNRA in all cases. Furthermore, Pett-Ridge et al. (2006) found that gross DNRA was unexpectedly higher in aerobic soils than in anoxic soils or in soils with fluctuating redox conditions. They explained this observation by higher $\mathrm{NO}_{3}^{-}$concentrations in aerobic soil and the possibility of the occurrence of DNRA in anaerobic soil aggregates. Previously, Silver et al. (2001) showed that the rate of DNRA can be limited by the availability of $\mathrm{NO}_{3}^{-}$that is caused by a small pool size in conjunction with high turnover. The DNRA rate constant, calculated as gross rate divided by $\mathrm{NO}_{3}^{-}$concentration, was, however, highest in anoxic soils (Pett-Ridge et al., 2006). Comparing the rate constant of denitrification and DNRA revealed that DNRA bacteria are more competitive for $\mathrm{NO}_{3}^{-}$under fluctuating redox conditions (Pett-Ridge et al., 2006). Thus, it appears that under certain environmental conditions DNRA bacteria are able to compete successfully with denitrifying bacteria for $\mathrm{NO}_{3}^{-}$, which supports the theoretical advantage of DNRA under low $\mathrm{NO}_{3}^{-}$concentrations (Tiedje et al., 1982; see Sect. 2).
Unfortunately analytical solutions for quantifying gross transformation rates, and particularly DNRA, introduce inconsistencies. These inconsistencies can occur when the assumption that no ${ }^{15} \mathrm{~N}$ is recycled into the labelled pool does not apply, when inappropriate kinetic settings for $\mathrm{N}$ transformations are used (Rütting and Müller, 2007) or if $\mathrm{NO}_{3}^{-}$ consumption and DNRA are calculated separately. Using an analytical model, Templer et al. (2008) found a higher gross rate for DNRA compared to total $\mathrm{NO}_{3}^{-}$consumption in one out of three tropical forest soils, which could have been due to inconsistencies. To overcome the problems associated with analytical solutions we recommend using numerical data analysis via so called ${ }^{15} \mathrm{~N}$ tracing models (Rütting and Müller, 2007; Rütting et al., 2011), which enables a simultaneous analysis of all $\mathrm{NO}_{3}^{-}$consumption pathways in a coherent model framework. This recommendation is in line with Silver at al. (2001) who stated that "numerical modeling may provide an alternative approach to explore the role of DNRA under a variety of scenarios". The only ${ }^{15} \mathrm{~N}$ tracing model that included DNRA was presented by Müller at al. (2004; 2007). An alternative approach to numerical tracing models was presented by Tietema and van Dam (1996), who combined ${ }^{15} \mathrm{~N}$ experiments with a simulation model. In this model DNRA was simulated as a function of microbial biomass, but was independent of substrate concentrations. However, to our knowledge this methodology has subsequently been applied in only one other study (Verburg et al., 1999), in which, moreover, DNRA was solely simulated as function of soil $\mathrm{C}$ content, as no tracing of ${ }^{15} \mathrm{NO}_{3}^{-}$ into ${ }^{15} \mathrm{NH}_{4}^{+}$was determined.

Application of the ${ }^{15} \mathrm{~N}$ tracing model developed by Müller et al. $(2004,2007)$ showed that DNRA is likely to occur in numerous ecosystems and was sometimes the dominant $\mathrm{NO}_{3}^{-}$ consumption process, as can be seen from the results of the studies summarised in Table 1. However, other investigations did not find evidence for DNRA (Cookson et al., 2006; Laughlin et al., 2008), confirming that DNRA may be important only in some, but not all ecosystems (Stanford et al., 1975). Such observations, however, may also be related to the experimental conditions. One additional advantage by using numerical ${ }^{15} \mathrm{~N}$ tracing models is that correlations between $\mathrm{N}$ transformations can be investigated (Müller et al., 2007). This enabled the detection of functional linkage between DNRA and the organic pathway of heterotrophic nitrification (oxidation of organic $\mathrm{N}$ ) in a Nothofagus forest on an Andisol in southern Chile (Rütting et al., 2008). The authors considered this link to be an adaptation of the microbial community with the result that $\mathrm{N}$ losses could be minimised. Recently two new bacterial species were described that performed simultaneously DNRA and heterotrophic nitrification (Behrendt et al., 2010), supporting the above proposed functional linkages. Such a functional link, if proved to be a general pattern in soil, could provide an alternative pathway of $\mathrm{NH}_{4}^{+}$production from soil organic matter to the 
Table 1. Summary of gross DNRA rates $\left[\mu \mathrm{g} \mathrm{N} \mathrm{g}^{-1}\right.$ soil day $\left.{ }^{-1}\right]$ in terrestrial ecosystems (mean \pm standard deviation, if available, or range of values) calculated by analytical (A) or numerical $(\mathrm{N}){ }^{15} \mathrm{~N}$ tracing models as well as the portion of DNRA to total gross $\mathrm{NO}_{3}^{-}$consumption $\left(\% \mathrm{C}_{\mathrm{NO}_{3}}\right)$.

\begin{tabular}{|c|c|c|c|c|c|c|}
\hline Ecosystem & Country $^{\mathrm{a}}$ & Method $^{b}$ & Model & DNRA rate & $\% \mathbf{C}_{\mathrm{NO}_{3}}$ & Ref. \\
\hline Riparian fen & DNK & Lsc & $\mathrm{A}$ & 0.36 & 2.8 & 1 \\
\hline Riparian zone & USA & Lsl & A & 1.3 & n.a. & 2 \\
\hline Arable field & AUT & $\mathrm{Lh}$ & A & $0.0-0.3$ & $0.0-6.3$ & 3 \\
\hline \multicolumn{7}{|c|}{ Temperate forest } \\
\hline Pine/Douglas fir & NLD & $\mathrm{Lh}$ & $\mathrm{N}$ & $0.01-0.25$ & $11.1-31.8$ & $4^{c}$ \\
\hline Spruce & SWE & $\mathrm{Lh}$ & A & 0.07 & 4 & $5^{d}$ \\
\hline Nothofagus & $\mathrm{CHL}$ & $\mathrm{Fi}$ & A & $1.00 \pm 0.20$ & 23.8 & 6 \\
\hline Nothofagus & CHL & $\mathrm{Lh}$ & $\mathrm{N}$ & $0.448 \pm 0.024$ & 99.3 & 7 \\
\hline Nothofagus & $\mathrm{CHL}$ & $\mathrm{Lh}$ & $\mathrm{N}$ & $0.355 \pm 0.016$ & 98.3 & 8 \\
\hline Oak & BEL & $\mathrm{Fi}$ & $\mathrm{N}$ & $0.012 \pm 0.001$ & 1.7 & 9 \\
\hline Pine & BEL & $\mathrm{Fi}$ & $\mathrm{N}$ & $0.004 \pm 0.001$ & 0.4 & 9 \\
\hline Various & $\mathrm{CHN}$ & $\mathrm{Lh}$ & $\mathrm{N}$ & $0.01-0.106$ & $4.5-100$ & 10 \\
\hline \multicolumn{7}{|c|}{ Subtropical forest } \\
\hline broadleaf & $\mathrm{CHN}$ & $\mathrm{Lh}$ & $\mathrm{N}$ & $0.053 \pm 0.009$ & 7.1 & 10 \\
\hline coniferous & $\mathrm{CHN}$ & $\mathrm{Lh}$ & $\mathrm{N}$ & $0.023 \pm 0.006$ & 2.9 & 10 \\
\hline broadleaf & $\mathrm{CHN}$ & Lh & $\mathrm{N}$ & $0.021 \pm 0.003$ & 15.6 & 11 \\
\hline coniferous & $\mathrm{CHN}$ & $\mathrm{Lh}$ & $\mathrm{N}$ & $0.015 \pm 0.008$ & 2.1 & 11 \\
\hline \multicolumn{7}{|c|}{ Tropical forest } \\
\hline Montane & PRI & $\mathrm{Fi}$ & A & $0.6 \pm 0.1$ & 75.0 & 12 \\
\hline Wet & PRI & $\mathrm{Lh}$ & A & $0.5-1.2$ & n.a. & 12 \\
\hline Humid & PRI & Lsc & A & $2.89 \pm 0.57$ & n.a. & $13^{\mathrm{e}}$ \\
\hline Plantation & CRI & $\mathrm{Fi}$ & A & $0.23 \pm 0.12$ & 10.6 & 14 \\
\hline Old-growth & CRI & $\mathrm{Fi}$ & A & $0.24 \pm 0.08$ & 4.6 & 14 \\
\hline Plantation & CRI & $\mathrm{Lh}$ & A & $0.33 \pm 0.12$ & n.a. & 14 \\
\hline Lowland & BRA & Lsc & A & $0.3-0.8$ & $12.1-50.0$ & 15 \\
\hline Humid & PRI & $\mathrm{Fi}$ & A & $0.03-1.27$ & $2.2-119.8$ & $16^{\mathrm{f}}$ \\
\hline Natural & $\mathrm{CHN}$ & $\mathrm{Lh}$ & $\mathrm{N}$ & $0.155 \pm 0.001$ & 9.8 & 10 \\
\hline \multicolumn{7}{|c|}{ Temperate grassland } \\
\hline Ryegrass field & USA & Lsl & $\mathrm{A}$ & 0.2 & n.a. & 2 \\
\hline Meadow & GER & $\mathrm{Lh}$ & $\mathrm{N}$ & 0.07 & 13.8 & 17 \\
\hline Meadow & GER & $\mathrm{Lh}$ & $\mathrm{N}$ & $0.090 \pm 0.003$ & 73.0 & 18 \\
\hline Meadow & GER & $\mathrm{Lh}$ & $\mathrm{N}$ & $0.090 \pm 0.003$ & 96.9 & 19 \\
\hline Meadow & GER & $\mathrm{Lh}$ & $\mathrm{N}$ & $0.27 \pm 0.01$ & 28.1 & 20 \\
\hline Pasture & NZL & $\mathrm{Lh}$ & $\mathrm{N}$ & $0.034 \pm 0.002$ & 0.6 & 21 \\
\hline
\end{tabular}

\footnotetext{
${ }^{\text {a }}$ AUT = Austria; BEL - Belgium; BRA - Brazil; CHL - Chile; CHN - China; CRI - Costa Rica; DNK - Denmark; FRA - France; GER - Germany; NLD - The Netherlands; NZL - New Zealand; PRI - Puerto Rico; SWE - Sweden; USA - United States of America

${ }^{\mathrm{b}} \mathrm{Fi}=$ Field incubation; $\mathrm{Lh}=$ Laboratory incubation using homogenised soil; Lsc = Laboratory incubation using soil cores; Lsl = Laboratory incubation using soil slurries

${ }^{c}$ DNRA rates were calculated by a simulation model as function of microbial biomass

$\mathrm{d}$ calculated based on data presented in Table 1 in the original publication for the unfertilized stand

e gross rate of initial redox treatment

$\mathrm{f}$ in one out of three forest soils the rate of DNRA was higher then total $\mathrm{NO}_{3}^{-}$consumption

References: 1 Ambus et al. (1992); 2 Davis et al. (2008); 3 Inselsbacher et al. (2010); 4 Tietema \& van Dam (1996); 5 Bengtsson and Bergwall (2000); 6 Huygens et al. (2008); 7 Huygens et al. (2007); 8 Rütting et al. (2008); 9 Staelens et al. (2011); 10 Zhang et al. (2011b); 11 Zhang et al. (2011a); 12 Silver et al. (2001); 13 Pett-Ridge et al. (2006); 14 Silver et al. (2005); 15 Sotta et al. (2008); 16 Templer et al. (2008); 17 Müller et al. (2004); 18 Müller et al. (2007); 19 Rütting and Müller (2008); 20 Müller et al. (2009); 21 Rütting et al. (2010)
} 


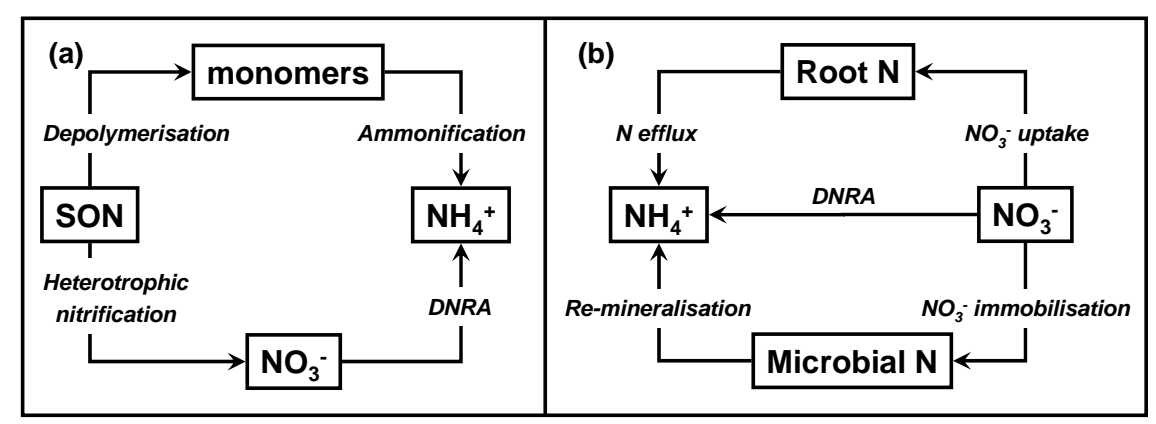

Fig. 1. Schematic overview of the importance of DNRA in soil: (a) as an alternative $\mathrm{NH}_{4}^{+}$producing process, when coupled to the organic pathway of heterotrophic nitrification, to mineralisation of soil organic nitrogen (SON) as described by Schimel and Bennett (2004); (b) alternative pathways transferring $\mathrm{NO}_{3}^{-}$to $\mathrm{NH}_{4}^{+}$in soil (Burger and Jackson, 2004) that can be evaluated by ${ }^{15} \mathrm{~N}$ tracing studies in combination with numerical data analysis if all the shown $\mathrm{N}$ pools are measured.

direct mineralisation pathway (Fig. 1a). In the Nothofagus forest DNRA accounted for more than $90 \%$ of total $\mathrm{NO}_{3}^{-}$ consumption (Rütting et al., 2008; Huygens et al., 2007). However, the transfer of ${ }^{15} \mathrm{~N}$ from $\mathrm{NO}_{3}^{-}$to $\mathrm{NH}_{4}^{+}$could in fact be due to three different pathways (Fig. 1b): (1) DNRA, (2) plant $\mathrm{N}$ efflux and (3) remineralisation by microorganisms (Burger and Jackson, 2004). Using data from a microcosm ${ }^{15} \mathrm{~N}$ study and simulation models Burger and Jackson (2004) provided evidence that each of the three pathways was on its own able to explain the observed ${ }^{15} \mathrm{~N}$ dynamics. Numerical ${ }^{15} \mathrm{~N}$ tracing models (e.g. Müller et al., 2007) have the potential to investigate the most likely pathway of $\mathrm{NO}_{3}^{-}$reduction to $\mathrm{NH}_{4}^{+}$when the ${ }^{15} \mathrm{~N}$ enrichment of roots, soil organic $\mathrm{N}$ and microbial biomass are measured in addition to the mineral $\mathrm{N}$ pools (Fig. 1b). The alternative pathways should be tested to identify via a likelihood analysis whether DNRA or alternative pathways occurred. In the above mentioned Nothofagus study these alternative pathways (plant $\mathrm{N}$ efflux and remineralisation) could be ruled out as no roots were present in the laboratory incubation and the ${ }^{15} \mathrm{~N}$ enrichment in five organic $\mathrm{N}$ fractions was too low to explain the ${ }^{15} \mathrm{NH}_{4}^{+}$enrichment by remineralisation (Rütting et al., 2008; Huygens et al., 2007). More detailed studies are needed to investigate the importance of the alternative pathways proposed by Burger and Jackson (2004), i.e. DNRA, plant $\mathrm{N}$ efflux and remineralisation by microorganisms, by combining ${ }^{15} \mathrm{~N}$ labelling studies with numerical data analysis.

Along a climate gradient in China, ranging from tropical to temperate zone, Zhang et al. (2011b) investigated gross $\mathrm{N}$ dynamics in 13 forest soils. In all but one soil gross DNRA activity was observed and DNRA was in half of the investigated soils the sole $\mathrm{NO}_{3}^{-}$consumption pathway. Highest gross DNRA was found for the tropical soil $\left(0.155 \mu \mathrm{g} \mathrm{N} \mathrm{g}^{-1}\right.$ soil day ${ }^{-1}$ ), whereas rates were similar for sub-tropical and temperate forest soils $\left(0.01-0.11 \mu \mathrm{g} \mathrm{Ng}^{-1}\right.$ soil day ${ }^{-1}$; Table 1). The soil not exhibiting DNRA dynamic was collected from a sub-tropical, evergreen broad-leaf forest, while all other soils were either from deciduous broad-leaf or conif- erous forests. This may point to an effect of the quality and quantity of plant litter on the DNRA activity, even though other studies did observe high gross DNRA rates in soil from tropical evergreen forests (e.g. Templer et al., 2008). Moreover, some studies compared the gross DNRA in soils from temperate and sub-tropical broad-leaf and coniferous forests (Zhang et al., 2011a; Zhang et al., 2011b; Staelens et al., 2011). In three out of four sites higher DNRA rates were observed in soil underneath broad-leaf species, which may be related to the fact that broad-leaves usually contain a higher amount of labile $\mathrm{C}$ compared to coniferous needles, which may stimulate DNRA (see Sect. 2). However, in the fourth site the DNRA was about twice as high under coniferous forest than broad leaf-forest, but the reason for this is not clear.

It was also shown that the soil type had a significant effect on DNRA, with higher rates in clay compared to sandy soil (Sotta et al., 2008). No explanation was provided for the differences, which are however likely due to the higher soil C and $\mathrm{N}$ content and higher anaerobicity in the clay soil. This is in line with findings from a Swedish catchment area, where higher gross DNRA was observed for organic compared to mineral soils, but the differences could be explained by differences in soil organic matter content and the gravimetric water content (Rütting et al, unpublished results).

\section{Effect of global change on DNRA}

The functional importance of DNRA in soil is its capacity to increase $\mathrm{N}$ retention, as $\mathrm{NO}_{3}^{-}$is transformed to $\mathrm{NH}_{4}^{+}$. Ammonium is available for plant and microbial uptake, but is less prone to losses via leaching or as gaseous compounds (Buresh and Patrick, 1978; Tiedje, 1988; Silver et al., 2001; Huygens et al., 2007). Current climate change scenarios suggest that many ecosystems may become increasingly $\mathrm{N}$ limited in the future. This is mainly due to increased atmospheric $\mathrm{CO}_{2}$ concentration, which can lead to a higher plant $\mathrm{N}$ demand (Hungate et al., 2003; Luo et al., 2004). The possible $\mathrm{N}$ limitation might be partially alleviated by increasing $\mathrm{N}$ 
Table 2. Results from Pearson Product Moment Correlation of (a) gross DNRA rates as well as (b) portion of gross DNRA to total gross $\mathrm{NO}_{3}^{-}$consumption $\left(\% \mathrm{C}_{\mathrm{NO}_{3}}\right)$ to measured environmental factors: soil $\mathrm{pH}$ (measured in water), total soil carbon and nitrogen (TC and TN), concentration of ammonium and nitrate $\left(\left[\mathrm{NH}_{4}^{+}\right]\right.$and $\left.\left[\mathrm{NO}_{3}^{-}\right]\right), \mathrm{C} / \mathrm{N}$ ratio, mean annual temperature and precipitation (MAT and MAP), incubation temperature $\left(T_{\text {inc }}\right)$, gravimetric water content $(\mathrm{GWC})$ and water filled pore space (WFPS).

(a) Gross DNRA rate

\begin{tabular}{|c|c|c|c|c|c|c|c|c|c|c|c|}
\hline & $\mathrm{pH}^{*}$ & $\mathrm{TN}^{*}$ & $\mathrm{TC}^{*}$ & {$\left[\mathrm{NH}_{4}^{+}\right]$} & {$\left[\mathrm{NO}_{3}^{-}\right]^{*}$} & $\mathrm{C} / \mathrm{N}^{*}$ & MAT* $^{*}$ & MAP* $^{*}$ & $T_{\text {inc }}{ }^{*}$ & GWC & WFPS \\
\hline$r$ & -0.164 & -0.053 & 0.395 & 0.070 & -0.209 & 0.290 & 0.163 & 0.425 & -0.086 & -0.011 & -0.026 \\
\hline $\mathrm{P}$ & 0.311 & 0.735 & 0.008 & 0.641 & 0.159 & 0.082 & 0.308 & 0.004 & 0.578 & 0.944 & 0.906 \\
\hline $\mathrm{N}$ & 40 & 43 & 44 & 47 & 47 & 37 & 41 & 45 & 44 & 41 & 23 \\
\hline \multicolumn{12}{|c|}{ (b) $\% \mathrm{C}_{\mathrm{NO}_{3}}$} \\
\hline & $\mathrm{pH}^{*}$ & $\mathrm{TN}^{*}$ & $\mathrm{TC}^{* *}$ & {$\left[\mathrm{NH}_{4}^{+}\right]$} & {$\left[\mathrm{NO}_{3}^{-}\right]^{*}$} & $\mathrm{C} / \mathrm{N}^{*}$ & MAT* & MAP* & $T_{\text {inc }}$ & GWC & WFPS* \\
\hline$r$ & 0.067 & -0.005 & 0.255 & 0.325 & 0.486 & -0.034 & -0.527 & 0.012 & -0.190 & -0.162 & -0.409 \\
\hline$P$ & 0.693 & 0.974 & 0.122 & 0.033 & 0.001 & 0.846 & 0.001 & 0.945 & 0.281 & 0.353 & 0.082 \\
\hline $\mathrm{N}$ & 37 & 40 & 38 & 43 & 43 & 35 & 34 & 36 & 34 & 35 & 19 \\
\hline
\end{tabular}

$r=$ Pearson's Correlation Coefficient; $\mathrm{P}=$ probability value; $\mathrm{N}=$ number of samples

* Variables used for multiple linear regression of gross DNRA and $\% \mathrm{C}_{\mathrm{NO}_{3}}$ as dependent variable, respectively. Not all variables could be considered due to the degree of freedom.

deposition (Johnson, 2006). However, Hungate et al. (2003) showed that the expected increase in $\mathrm{N}$ deposition will not cover the additional $\mathrm{N}$ demand under elevated $\mathrm{CO}_{2}$, indicating that $\mathrm{N}$ retention processes such as DNRA may become more important for ecosystem productivity.

Tietema and van Dam (1996) investigated the effect of increased $\mathrm{N}$ deposition on the $\mathrm{N}$ cycle in two coniferous forest soils. At one site they found higher DNRA under preindustrial (1-2 $\mathrm{kg} \mathrm{Nha}^{-1} \mathrm{yr}^{-1}$ ) compared to increased deposition (31-37 kg N ha $\mathrm{kr}^{-1}$ ), while no effect was found for the second forest. In a forest $\mathrm{N}$ fertilisation experiment in Sweden no clear pattern of the relationship between the amount of fertiliser applied $\left(0-180 \mathrm{~kg} \mathrm{~N} \mathrm{ha}^{-1} \mathrm{yr}^{-1}\right)$ and ${ }^{15} \mathrm{NO}_{3}^{-}$reduction to ${ }^{15} \mathrm{NH}_{4}^{+}$was found (Bengtsson and Bergwall, 2000). Kandeler et al. (2009), however, found lower total nitrate reductase activity in soil where $\mathrm{N}$ deposition was decreased, although the total number of nitrate reduction genes was not affected. The effect of elevated $\mathrm{CO}_{2}$ on $\mathrm{N}$ cycling rates, including DNRA, was recently investigated in soils from two long-term free air $\mathrm{CO}_{2}$ enrichment studies on temperate grassland (Müller et al., 2009; Rütting et al., 2010). In both of these studies DNRA was stimulated under elevated $\mathrm{CO}_{2}$ by 140 and $44 \%$, respectively, most likely due to an increased $\mathrm{C}$ input into the soil that stimulated microbial activity and possibly increased anaerobicity.

\section{Importance and regulation of DNRA}

Summarising the findings of ${ }^{15} \mathrm{~N}$ labelling studies indicates that the occurrence of DNRA is more widely spread in soils than previously thought (Table 1). Notably, only one study has reported gross DNRA rates in an arable soil (Inselsbacher et al., 2010) and none for boreal ecosystems, indi- cating that further studies in these ecosystems are needed. In the biomes where data are available (temperate and (sub)tropical forest as well as temperate grassland) the importance of DNRA (measured as contribution to total $\mathrm{NO}_{3}^{-}$consumption, $\% \mathrm{C}_{\mathrm{NO}_{3}}$ ) range from negligible to dominant (Table 1). This poses the question which environmental factors do regulate the rates and the importance of DNRA in soil. The best way to approach this question would be to conduct a meta-analysis. However, this is hindered by two facts. First, there is a lack of data on environmental factors in the literature. Notably, almost none of the studies on gross DNRA have reported the soil organic matter content, which has been identified as the best predictor for DNRA in a Swedish catchment (Rütting et al., unpublished results). Second, no general agreement has been reached on the most suitable method to quantify gross DNRA rates. As mentioned above two approaches have been used, applying either analytical or numerical data analysis. Moreover, some of the studies have used the classical pool dilution technique which is not suitable to resolve the simultaneously occurring $\mathrm{NO}_{3}^{-}$reduction pathways (e.g. Silver et al., 2001; Sotta et al., 2008; Inselsbacher et al., 2010). The quantification of gross DNRA requires a "mirror labeling" approach (Barraclough, 1997) in order to assure the same microbial activity in both ${ }^{15} \mathrm{~N}$ labeling treatments.

We conducted some statistical analyses with the available data set (see Supplement Table SI-1) using SigmaPlot (Version 11, Systat Software, Inc.). Based on Pearson's correlation (Table 2a) there were significant positive correlations of gross DNRA with mean annual precipitation (MAP) and total soil C (TC) and gross DNRA tended to be poritively correlated to the $\mathrm{C} / \mathrm{N}$ ratio. As a next step we conducted multiple linear regressions (stepwise forward approach) to find combinations of variables that best predict gross DNRA in soils. 
Gross DNRA rates were best explained by a combination of mean annual temperature (MAT) and MAP $\left(R^{2}=0.38\right)$ according to:

$\mathrm{DNRA}=-0.0714+0.0102 \cdot \mathrm{MAT}+6.13 \times 10^{-5} \cdot \mathrm{MAP}$

These findings provide an indication that gross DNRA rates are influenced by the climatic conditions as well as edaphic factors.

High gross rates must not necessarily mean a high importance in an ecosystem. Therefore we calculated the portion of DNRA to total gross $\mathrm{NO}_{3}^{-}$consumption $\left(\% \mathrm{C}_{\mathrm{NO}_{3}}\right)$ and conducted statistical analyses in order to identify the importance of DNRA in the studied ecosystems. There is a significant correlation of $\% \mathrm{C}_{\mathrm{NO}_{3}}$ with the concentration of both mineral $\mathrm{N}$ forms $\left(\mathrm{NH}_{4}^{+}\right.$and $\left.\mathrm{NO}_{3}^{-}\right)$, MAT as well as the water filled pore space (WFPS; Table 2b). Notably, the correlation to WFPS and MAT are negative. The results from the multiple linear regression showed that $\% \mathrm{C}_{\mathrm{NO}_{3}}$ can be predicted from a linear combination of total soil $\mathrm{N}(\mathrm{TN})$ and WFPS $\left(R^{2}=0.76\right)$ :

$\% \mathrm{C}_{\mathrm{NO}_{3}}=90.279+101.185 \cdot \mathrm{TN}-1.338 \cdot \mathrm{WFPS}$

Taken together, these results indicate that highest gross DNRA can be expected in soils with a high soil C (and possibly organic matter) content in humid regions. Indeed, highest gross DNRA has been reported for tropical and temperate rainforests (Table 1). However, the relative importance of DNRA (measured as $\% \mathrm{C}_{\mathrm{NO}_{3}}$ ) seems to be higher in temperate climates (Table 2a) in soil with lower soil moisture. This later finding seems to contradict with the anoxic nature of DNRA (see Sect. 2), but may be explained by the higher $\mathrm{NO}_{3}^{-}$availability in less moist soils or by the higher tolerance of DNRA to changing redox conditions and $\mathrm{O}_{2}$ compared to denitrification (Pett-Ridge et al., 2006; Fazzolari et al., 1998).

\section{Conclusions}

More than thirty years ago Cole and Brown (1980) concluded that the significance of DNRA in anaerobic soil was unknown. Now, with the use of ${ }^{15} \mathrm{~N}$ labelling techniques and the quantification of gross DNRA rates, the hypothesis that DNRA "may be much more important than presently realized" (Stevens et al., 1998) seems to be confirmed. Gross DNRA rates can be quantified via ${ }^{15} \mathrm{~N}$ tracing studies in combination with numerical data analysis and ${ }^{15} \mathrm{~N}$ tracing models that consider DNRA as well as all $\mathrm{N}$ transformations that interact with each other (Rütting et al., 2011). A particularly powerful tool for future investigations can be the combination of ${ }^{15} \mathrm{~N}$ tracing and molecular approaches (Wallenstein and Vilgalys, 2005; Philippot and Hallin, 2005). Summarising the findings of several studies, we conclude that DNRA is a significant, or even dominant, $\mathrm{NO}_{3}^{-}$consumption process in some ecosystems (Table 1). The importance of DNRA may even increase under current climate change scenarios. Previously, it was concluded that the potential for significant DNRA exists in most soils, but that it is only expressed under anoxic conditions when $\mathrm{C}$ is readily available, possibly in anaerobic micro-sites (Smith and Zimmerman, 1981; Caskey and Tiedje, 1979). Yin et al. (1998) showed that a soil $\mathrm{C} / \mathrm{NO}_{3}^{-}$ratio above 12 seems to be a threshold for significant DNRA activity, but more studies are needed to ascertain if this threshold is a general feature or variable depending on soil properties. As Burgin and Hamilton (2007) concluded for aquatic systems, more work is also needed to understand the importance of DNRA in various terrestrial ecosystems. Therefore, future investigations on the soil $\mathrm{N}$ cycle in different terrestrial ecosystems (forest, agricultural land, grassland, wetland) should focus not only on 'classical' N cycling processes such as nitrification, denitrification and mineralisation, but also should include processes such as DNRA, because the occurrence of this process is often an indicator for ecosystem $\mathrm{N}$ retention. Finally, the $\mathrm{N}$ mineralisation paradigm of Schimel and Bennett (2004) should be adapted and include DNRA as an alternative $\mathrm{NH}_{4}^{+}$producing process, in particular in conjunction with the postulated link to the organic pathway of heterotrophic nitrification (Fig. 1). An improved understanding of the conditions that govern whether $\mathrm{NO}_{3}^{-}$is reduced to gaseous $\mathrm{N}$ or $\mathrm{NH}_{4}^{+}$could also provide possible mitigation scenarios for $\mathrm{N}_{2} \mathrm{O}$.

\section{Supplement related to this article is available online at: http://www.biogeosciences.net/8/1779/2011/ bg-8-1779-2011-supplement.pdf.}

Acknowledgements. Financial support for this study came from the NitroEurope IP under the EC 6th Framework Programme (Contract No. 017841) and the Swedish Research Council for Environment, Agricultural Sciences and Spatial Planning (FORMAS). This work was conducted within Tellus (The Centre of Earth Systems Science, University of Gothenburg). We would like to thank the reviewers A. R. Mosier, W. Wanek and N. Wrage for their valuable comments on the discussion paper.

Edited by: N. Buchmann

\section{References}

Ambus, P., Mosier, A. R., and Christensen, S.: Nitrogen turnover rates in a riparian fen determined by ${ }^{15} \mathrm{~N}$ dilution, Biol. Fertil. Soil., 14, 230-236, 1992.

Barraclough, D.: The direct or MIT route for nitrogen immobilization: a ${ }^{15} \mathrm{~N}$ mirror image study with leucine and glycine, Soil Biol. Biochem., 29, 101-108, 1997.

Behrendt, U., Schumann, P., Stieglmeier, M., Pukall, R., Augustin, J., Spröer, C., Schwendner, P., Moissl-Eichinger, C., and Andreas, U.: Characterization of heterotrophic nitrifying bacteria with respiratory ammonification and denitrification activity 
- Description of Paenibacillus uliginis sp. nov., an inhabitant of fen peat soil and Paenibacillus purispatii sp. nov., isolated from a spacecraft assembly clean room, Syst. Appl. Microbiol., 33, 328-336, 2010.

Bengtsson, G. and Bergwall, C.: Fate of ${ }^{15} \mathrm{~N}$ labelled nitrate and ammonium in a fertilized forest soil, Soil Biol. Biochem., 32, 545-557, 2000.

Bleakley, B. H. and Tiedje, J. M.: Nitrous oxide production by organisms other than nitrifiers or denitrifiers, Appl. Environ. Microbiol., 44, 1342-1348, 1982.

Brunel, B., Janse, J. D., Laanbroek, H. J., and Woldendorp, J. W.: Effect of transient oxic conditions on the composition of the nitrate-reducing community from the rhizosphere of Typha angustifolia, Microbial Ecology, 24, 51-61, 1992.

Brunet, R. C. and Garcia-Gill, L. J.: Sulfide-induced dissimilatory nitrate reduction to ammonia in anaerobic freshwater sediments, FEMS Microbiology Ecology, 21, 131-138, 1996.

Buresh, R. J. and Patrick, W. H., Jr.: Nitrate reduction to ammonium in anaerobic soil, Soil Sci. Soc. Am. J., 42, 913-918, 1978.

Burgin, A. J. and Hamilton, S. K.: Have we overemphasized the role of denitrification in aquatic ecosystems? A review of nitrate removal pathways, Frontier in Ecology and Environment, 5, 8996, 2007.

Burger, M. and Jackson, L. E.: Plant and microbial use and turnover: rapid conversion of nitrate to ammonium in soil with roots, Plant Soil, 266, 289-301, 2004.

Caskey, W. H. and Tiedje, J. M.: Evidence for Clostridia as agents of dissimilatory reduction of nitrate to ammonium in soils, Soil Sci. Soc. Am. J., 43, 931-936, 1979.

Chen, D. L., Chalk, P. M., and Freney, J. R.: Distribution of reduced products of ${ }^{15} \mathrm{~N}$-labelled nitrate in anaerobic soils, Soil Biol. Biochem., 27, 1539-1545, 1995.

Cole, J. A.: Assimilatory and dissimilatory reduction of nitrate to ammonia, in: The Nitrogen and Sulphur Cycles, edited by: Cole, J. A. and Ferguson, S. J., Cambridge University Press, Cambridge, 281-329, 1988.

Cole, J. A.: Physiology, biochemistry and genetics of nitrate dissimilation to ammonia, in: Denitrification in Soil and Sediment, edited by: Revsbech, N. P., and Sørensen, J., Plenum Press, New York, USA, 57-76, 1990.

Cole, J. A. and Brown, C. M.: Nitrite reduction to ammonia by fermentative bacteria: a short circuit in the biological nitrogen cycle, FEMS Microbiol. Lett., 7, 65-72, 1980.

Cookson, W. R., Müller, C., O’Brien, P. A., Murphy, D. V., and Grierson, P. F.: Nitrogen dynamics in an Australian semi-arid grassland soil, Ecology, 87, 2047-2057, 2006.

Davidson, T. E. and Ståhl, M.: The influence of organic carbon on nitrogen transformations in five wetland soils, Soil Sci. Soc. Ame. J., 64, 1129-1136, 2000.

Davis, J. H., Griffith, S. M., Horwath, W. R., Steiner, J. J., and Myrold, D. D.: Denitrification and nitrate consumption in an herbaceous riparian area and perennial ryegrass seed cropping system, Soil Sci. Soc. Am. J., 72, 1299-1310, 2008.

deCatanzaro, J. B., Beauchamp, E. G., and Drury, C. F.: Denitrification vs dissimilatory nitrate reduction in soil with alfalfa, straw, glucose and sulfide treatments, Soil Biol. Biochem., 19, 583587, 1987.

Dhondt, K., Boeckx, P., Van Cleemput, O., and Hofman, G.: Quantifying nitrate retention processes in a riparian buffer zone using the natural abundance of ${ }^{15} \mathrm{~N}$ in $\mathrm{NO}_{3}^{-}$, Rapid Comm. Mass Spectrom., 17, 2597-2604, 2003.

Dunn, G. M., Herbert, R. A., and Brown, C. M.: Influence of oxygen tension on nitrate reduction by a Klebsiella sp. growing in chemostat culture, J. General Microbiol., 112, 379-383, 1979.

Eschbach, M., Möbitz, H., Rompf, A., and Jahn, D.: Members of the genus Arthrobacter grow anaerobically using nitrate ammonification and fermentative processes: anaerobic adaptation of aerobic bacteria abundant in soil, FEMS Microbiol. Lett., 223, 227-230, 2003.

Fazzolari, É., Mariotti, A., and Germon, J. C.: Dissimilatory ammonia production vs. denitrification in vitro and in inoculated agricultural soil samples, Canad. J. Microbiol., 36, 786-793, 1990.

Fazzolari, É., Nicolardot, B., and Germon, J. C.: Simultaneous effects of increasing levels of glucose and oxygen partial pressures on denitrification and dissimilatory reduction to ammonium in repacked soil cores, Europ. J. Soil Biol., 34, 47-52, 1998.

Fazzolari Correa, É., and Germon, J. C.: Dissimilative nitrate reduction to ammonium in different soils in waterlogged conditions, in: Diversity of Environmental Biogeochemistry, edited by: Berthelin, J., Developments in Geochemistry, Elsevier, Amsterdam, The Netherlands, 295-308, 1991.

Francis, C. A., Beman, J. M., and Kuypers, M. M. M.: New processes and players in the nitrogen cycle: the microbial ecology of anaerobic and archaeal ammonia oxidation, ISME Journal, 1, 19-27, 2007.

Freitag, A., Rudert, M., and Bock, E.: Growth of Nitrobacter by dissimilatoric nitrate reduction, FEMS Microbiology Letters, 48, 105-109, 1987.

Gamble, T. N., Betlach, M. R., and Tiedje, J. M.: Numerically dominant denitrifying bacteria from world soils, Applied and Environmental Microbiology, 33, 926-939, 1977.

Gottschalk, G.: Bacterial metabolism, 2. ed., Springer, New York, USA, 359 pp., 1986.

Hart, S. C. and Myrold, D. D.: ${ }^{15} \mathrm{~N}$ tracer studies of soil nitrogen transformations, in: Mass spectrometry of soils, edited by: Boutton, T. W., and Yamasaki, S. i., Marcel Dekker, Inc., New York, USA, 225-245, 1996.

Hayatsu, M., Tago, K., and Saito, M.: Various players in the nitrogen cycle: diversity and functions of the microorganisms involved in nitrification and denitrification, Soil Sci. Plant Nutr., 54, 33-45, 2008.

Hungate, B. A., Dukes, J. S., Shaw, M. R., Luo, Y., and Field, C. B.: Nitrogen and climate change, Science, 302, 1512-1513, 2003.

Huygens, D., Rütting, T., Boeckx, P., Van Cleemput, O., Godoy, R., and Müller, C.: Soil nitrogen conservation mechanisms in a pristine south Chilean Nothofagus ecosystem, Soil Biol. Biochem., 39, 2448-2458, 2007.

Huygens, D., Boeckx, P., Templer, P. H., Paulino, L., Van Cleemput, O., Oyarzún, C. E., Müller, C., and Godoy, R.: Mechanisms for retention of bioavailable nitrogen in volcanic rainforest soil, Nature Geosci., 1, 543-548, 2008.

Inselsbacher, E., Hinko-Najera Umana, N., Stange, F. C., Gorfer, M., Schüller, E., Ripka, K., Zechmeister-Boltenstern, S., HoodNovotny, R., Strauss, J., and Wanek, W.: Short-term competition between crop plants and soil microbes for inorganic $\mathrm{N}$ fertilizer, Soil Biol. Biochem., 42, 360-372, 2010.

Johnson, D. W.: Progressive N limitation in forests: review and implications for long-term responses to elevated $\mathrm{CO}_{2}$, Ecology, 
87, 64-75, 2006.

Kandeler, E., Brune, T., Enowashu, E., Dörr, N., Guggenberger, G., Lamersdorf, N., and Philippot, L.: Response of total and nitratedissimilating bacteria to reduced $\mathrm{N}$ deposition in a spruce forest soil profile, FEMS Microbiol. Ecol., 67, 444-454, 2009.

Kaspar, H. F.: Nitrite reduction to nitrous oxide by propionibacteria: detoxication mechanism, Archives of Microbiology, 133, 126130, 1982.

Klemedtsson, L., Svensson, B. H., and Rosswall, T.: Dinitrogen and nitrous oxide produced by denitrification and nitrification in soil with and without barley plants, Plant Soil, 99, 303-319, 1987.

Kraft, B., Strous, M., and Tegetmeyer, H. E.: Microbial nitrate respiration - Genes, enzymes and environmental distribution, J. Biotechnol., doi:10.1016/j.jbiotec.2010.12.025, 2011.

Laughlin, R. J., Stevens, C. J., Müller, C., and Watson, C.: Evidence that fungi can oxidize $\mathrm{NH}_{4}^{+}$to $\mathrm{NO}_{3}^{-}$in a grassland soil, Europ. J. Soil Sci., 59, 285-291, 2008.

Luo, Y., Currie, W. S., Dukes, J. S., Finzi, A. C., Hartwig, U., Hungate, B. A., McMurtrie, R. E., Oren, R., Parton, W. J., Pataki, D. E., Shaw, M. R., Zak, D. R., and Field, C. B.: Progressive nitrogen limitation of ecosystem responses to rising atmospheric carbon dioxide, BioScience, 54, 731-739, 2004.

MacRae, I. C., Ancajas, R. R., and Salandanan, S.: The fate of nitrate nitrogen in some tropical soils following submergence, Soil Sci., 105, 327-334, 1968.

Matheson, F. E., Nguyen, M. L., Cooper, A. B., Burt, T. P., and Bull, D. C.: Fate of ${ }^{15} \mathrm{~N}$-nitrate in unplanted, planted and harvested riparian wetland soil microcosms, Ecol. Eng., 19, 249-264, 2002.

Mohan, S. B. and Cole, J. A.: The dissimilatory reduction of nitrate to ammonia by anaerobic bacteria, in: Biology of the Nitrogen Cycle, edited by: Bothe, H., Ferguson, S. J., and Newton, W. E., Elsevier, Amsterdam, The Netherlands, 93-106, 2007.

Mohan, S. B., Schmid, M., Jetten, M. S. M., and Cole, J.: Detection and widespread distribution of the nrfA gene encoding nitrite reduction to ammonia, a short circuit in the biological nitrogen cycle that competes with denitrification, FEMS Microbiol. Ecol., 49, 433-443, 2004.

Moreno-Vivián, C. and Ferguson, S. J.: Definition and distinction between assimilatory, dissimilatory and respiratory pathways, Molec. Microbiol., 29, 661-669, 1998.

Morley, N. and Baggs, E. M.: Carbon and oxygen control of $\mathrm{N}_{2} \mathrm{O}$ and $\mathrm{N}_{2}$ production during nitrate reduction, Soil Biol. Biochem., 42, 1864-1871, 2010.

Müller, C., Stevens, R. J., and Laughlin, R. J.: A ${ }^{15} \mathrm{~N}$ tracing model to analyse $\mathrm{N}$ transformations in old grassland soil, Soil Biol. Biochem., 36, 619-632, 2004.

Müller, C., Rütting, T., Kattge, J., Laughlin, R. J., and Stevens, R. J.: Estimation of parameters in complex ${ }^{15} \mathrm{~N}$ tracing models via Monte Carlo sampling, Soil Biology \& Biochemistry, 39, 715726, 2007.

Müller, C., Rütting, T., Abbasi, M. K., Laughlin, R. J., Kammann, C., Clough, T. J., Sherlock, R. R., Kattge, J., Jäger, H. J., Watson, C. J., and Stevens, R. J.: Effect of elevated $\mathrm{CO}_{2}$ on soil $\mathrm{N}$ dynamics in a temperate grassland soil, Soil Biol. Biochem., 41, 1996-2001, 2009.

Myers, R. J. K.: The effect of sulphide on nitrate reduction in soil, Plant and Soil, 37, 431-433, 1972.

Nijburg, J. W. and Laanbroek, H. J.: The influence of Glyceria maxima and nitrate input on the composition and nitrate metabolism of the dissimilatory nitrate-reducing bacterial community, FEMS Microbiol. Ecol., 22, 57-63, 1997a.

Nijburg, J. W. and Laanbroek, H. J.: The fate of ${ }^{15} \mathrm{~N}$-nitrate in healthy and declining Phragmites australis stands, Microb. Ecol., 34, 254-262, 1997b.

Nishio, T.: Estimating nitrogen transformation rates in surface aerobic soil of a paddy field, Soil Biol. Biochem., 26, 1273-1280, 1994.

Nõmmik, H.: Investigations on denitrification in soil, Acta Agriculturæ Scandinavica, 6, 195-228, 1956.

Page, K. L., Dalal, R. C., and Menzies, N. W.: Nitrate ammonification and its relationship to the accumulation of ammonium in a vertisol subsoil, Austr. J. Soil Res., 41, 687-697, 2003.

Paul, J. W. and Beauchamp, E. G.: Denitrification and fermentation in plant-residue-amended soil, Biol. Fertil. Soil., 7, 303-309, 1989.

Pett-Ridge, J., Silver, W. L., and Firestone, M. K.: Redox fluctuations frame microbial community impacts on $\mathrm{N}$-cycling rates in humid tropical forest soil, Biogeochemistry, 81, 95-110, 2006.

Philippot, L.: Tracking nitrate reducers and denitrifiers in the environment, Biochem. Soc. Trans., 33, 200-204, 2005.

Philippot, L. and Hallin, S.: Finding the missing link between diversity and activity using denitrifying bacteria as a model functional community, Current Opinion in Microbiology, 8, 234-239, 2005.

Philippot, L. and Højberg, O.: Dissimilatory nitrate reductases in bacteria, Biochim. Biophys. Acta, 1446, 1-23, 1999.

Philippot, L., Hallin, S., Börjesson, G., and Baggs, E. M.: Biochemical cycling in the rhizosphere having an impact on global change, Plant and Soil, 321, 61-81, 2009.

Polcyn, W. and Podeszwa, J.: Coordinate induction of dissimilatory ammonification and fermentative pathways in rhizobia, Antonie van Leeuwenhoek, 96, 79-87, doi:10.1007/s10482-009-9338-3, 2009.

Rütting, T. and Müller, C.: ${ }^{15} \mathrm{~N}$ tracing models with a Monte Carlo optimization procedure provide new insights on gross $\mathrm{N}$ transformations in soil, Soil Biol. Biochem., 39, 2351-2361, 2007.

Rütting, T. and Müller, C.: Process-specific analysis of nitrite dynamics in a permanent grassland soil by using a Monte Carlo sampling technique, Europ. J. Soil Sci., 59, 208-215, 2008.

Rütting, T., Huygens, D., Müller, C., Van Cleemput, O., Godoy, R., and Boeckx, P.: Functional role of DNRA and nitrite reduction in a pristine south Chilean Nothofagus forest, Biogeochemistry, 90, 243-258, 2008.

Rütting, T., Clough, T. J., Müller, C., Lieffering, M., and Newton, P. C. D.: Ten years of elevated atmospheric $\mathrm{CO}_{2}$ alters soil $\mathrm{N}$ transformations in a sheep-grazed pasture, Global Change Biol., 16, 2530-2542, 2010.

Rütting, T., Huygens, D., Staelens, J., Müller, C., and Boeckx, P.: Advances in ${ }^{15} \mathrm{~N}$ tracing experiments: new labelling and data analysis approaches, Biochem. Soc. Trans., 39, 279-283, 2011.

Schimel, J. P. and Bennett, J.: Nitrogen mineralization: challenges of a changing paradigm, Ecology, 85, 591-602, 2004.

Silver, W. L., Herman, D. J., and Firestone, M. K.: Dissimilatory nitrate reduction to ammonium in upland tropical forest soils, Ecology, 82, 2410-2416, 2001.

Silver, W. L., Thompson, A. W., Reich, A., Ewel, J. J., and Firestone, M. K.: Nitrogen cycling in tropical plantation forests: potential controls on nitrogen retention, Ecol. Appl., 15, 1604$1614,2005$. 
Šimek, M., and Cooper, J. E.: The influence of soil pH on denitrification: progress towards the understanding of this interaction over the last 50 years, Europ. J. Soil Sci., 53, 345-354, 2002.

Simon, J.: Enzymology and bioenergetics of respiratory nitrite ammonification, FEMS Microbiol. Rev., 26, 285-309, 2002.

Smith, M. S.: Dissimilatory reduction of $\mathrm{NO}_{2}^{-}$to $\mathrm{NH}_{4}^{+}$and $\mathrm{N}_{2} \mathrm{O}$ by a soil Citrobacter sp, Appl. Environ. Microbiol., 43, 854-860, 1982.

Smith, M. S. and Zimmerman, K.: Nitrous oxide production by nondenitrifying soil nitrate reducers, Soil Sci. Soc. Am. J., 45, 865-871, 1981.

Sotta, E. D., Corre, M. D., and Veldkamp, E.: Differing N status and $\mathrm{N}$ retention processes of soils under old-growth lowland forest in Eastern Amazonia, Caxiuanã, Brazil, Soil Biol. Biochem., 40, 740-750, 2008.

Staelens, J., Rütting, T., Huygens, D., De Schrijver, A., Müller, C., Verheyen, K., and Boeckx, P.: In situ gross nitrogen transformations differ between temperate deciduous and coniferous forest soils, Biogeochemistry, doi:10.1007/s10533-10011-1959810537, 2011.

Stanford, G., Legg, J. O., Dzienia, S., and Simpson Jr., E. C.,: Denitrification and associated nitrogen transformations in soils, Soil Sci., 120, 147-152, 1975.

Stevens, R. J. and Laughlin, R. J.: Measurement of nitrous oxide and di-nitrogen emissions from agricultural soils, Nutrient Cycling in Agroecosystems, 52, 131-139, 1998.

Stevens, R. J., Laughlin, R. J., and Malone, J. P.: Soil pH affects the processes reducing nitrate to nitrous oxide and di-nitrogen, Soil Biol. Biochem., 30, 1119-1126, 1998.

Strohm, T. O., Griffin, B., Zumft, W. G., and Schink, B.: Growth yields in bacterial denitrification and nitrate ammonification, Appl. Environ. Microbiol., 73, 1420-1424, 2007.

Takaya, N.: Dissimilatory nitrate reduction metabolisms and their control in fungi, J. Biosci. Bioeng., 94, 506-510, 2002.

Templer, P. H., Silver, W. L., Pett-Ridge, J., DeAngelis, K. M., and Firestone, M. K.: Plant and microbial controls on nitrogen retention and loss in a humid tropical forest, Ecology, 89, 3030-3040, 2008.

Tiedje, J. M., Sexstone, A. J., Myrold, D. D., and Robinson, J. A.: Denitrification: ecological niches, competition and survival, Antonie van Leeuwenhoek Journal of Microbiology, 48, 569-583, 1982.

Tiedje, J. M.: Ecology of denitrification and dissimilatory nitrate reduction to ammonium, in: Biology of Anaerobic Microorganisms, edited by: Zehnder, A. J. B., John Wiley \& Sons, New York, USA, 179-244, 1988.
Tietema, A. and Van Dam, D.: Calculating microbial carbon and nitrogen transformations in acid forest litter with ${ }^{15} \mathrm{~N}$ enrichment and dynamic simulation modelling, Soil Biol. Biochem., 28, 953-965, 1996.

Verburg, P. S. J., Van Dam, D., Hefting, M. M., and Tietema, A.: Microbial transformations of $\mathrm{C}$ and $\mathrm{N}$ in a boreal forest floor as affected by temperature, Plant Soil, 208, 187-197, 1999.

Wallenstein, M. D. and Vilgalys, R. J.: Quantitative analyses of nitrogen cycling genes in soils, Pedobiologia, 49, 665-672, 2005.

Wan, Y., Ju, X., Ingwersen, J., Schwarz, U., Stange, C. F., Zhang, F., and Streck, T.: Gross nitrogen transformations and related nitrous oxide emissions in an intensively used calcareous soil, Soil Sci. Soc. Am. J., 73, 102-112, 2009.

Waring, S. A. and Gilliam, J. W.: The effect of acidity on nitrate reduction and denitrification in lower coastal plain soil, Soil Sci. Soc. Am. J., 42, 246-251, 1983.

Woldendorp, J. W.: The influence of living plants on denitrification, Medelingen van de Landbouwhogeschool te Wageningen, Nederland, 63, 1-100, 1963.

Woods, D. D.: The reduction of nitrate to ammonia by Clostridium welchii, Biochem. J., 32, 2000-2012, 1938.

Yin, S., Shen, Q., Tang, Y., and Cheng, L.: Reduction of nitrate to ammonium in selected paddy soils in China, Pedosphere, 8 , 221-228, 1998.

Yin, S. X., Chen, D., Chen, L. M., and Edis, R.: Dissimilatory nitrate reduction to ammonium and responsible microorganisms in two Chinese and Australian paddy soils, Soil Biol. Biochem., 34, 1131-1137, 2002.

Zhang, J., Müller, C., Zhu, T., Chen, Y., and Cai, Z.: Heterotrophic nitrification is the predominant $\mathrm{NO}_{3}^{-}$production mechanism in coniferous but not broad-leaf acid forest soil in subtropical China, Biol. Fert. Soil., 47, 533-542, 2011a.

Zhang, J., Zhu, T., Cai, Z., and Müller, C.: Nitrogen cycling in forest soils across climate gradients in Eastern China, Plant Soil, 342, 419-432, $2011 b$.

Zhou, Z., Takaya, N., Nakamura, A., Yamaguchi, M., Takeo, K., and Shoun, H.: Ammonia fermentation, a novel anoxic metabolism of nitrate by fungi, J. Biol. Chem., 277, 1892-1896, 2002.

Zumft, W. G.: Cell biology and molecular basis of denitrification, Microbiol. Molec. Biol. Rev., 61, 533-616, 1997. 